\title{
Innovative methods of industrial enterprises management based on the universal network model
}

\author{
Nikolay Glushak ${ }^{1}$, Olga Glushak ${ }^{1}$, Zinaida Shuklina ${ }^{1}$, Tatyana Gerashchenkova ${ }^{2}$ \\ ${ }^{1}$ I.G. Petrovsky Bryansk State University, 14, Bezhytskaya, 241036, Bryansk, Russia \\ ${ }^{2}$ Bryansk State Technical University, 7, Bulvar 50-letia Octiabria, 243360, Bryansk, Russia
}

\begin{abstract}
The article presents the results of research on the innovations in the sphere of industrial enterprises in Russia. A number of evolutionary factors causing obsolescence of the existing theoretical concepts of the innovation processes in the industry were identified. As a result of the study, we developed a universal (standard) model for the organization of the innovation network, which is superimposed on the actual organizational unions in the industrial sphere, integrating the administrative mechanisms laid in them.
\end{abstract}

\section{Introduction}

At the present stage of the world economy development, the key factor in national and local competitiveness is uniquely determined by the level of innovation of the industrial sector. The transition to technological mode VI determines not only the priority of the new industrial development vectors presented in the "NBICconvergence" concept, but also sets a new - Network concept of organizational and economic interactions between the participants of the innovation process (government, industry and consumer) $[1,2]$.

Experts predict that by 2020, the current economy based on indirect relations will be replaced by the network economy. The network organizational principle for innovative activity of the industrial sector is defined as a promising organizational and economic paradigm of competitiveness. It is the one that is an alternative to the "infrastructure", "transfer" and "cluster" approaches, studied in the current theoretical models of innovation activity based on the "technology platforms."

Unfortunately, the current Russia's position in the global innovation rankings looks depressing. In 2014 Russia was rated 49 in the general ranking, between Thailand (48) and Greece (50), being upraised 13 points at once. Strengths of Russia are the quality of human capital (position 30), business development (43), the development of knowledge and technology (34). The infrastructure development indicators remain at an average level (position 51). The innovations are hindered by imperfect institutions (position 88), poor performance of creative activity (72) and development of the internal market (111). Among BRICS countries, Russia ranks second after China (position 29, while China's rating is now comparable with the rating of many high-income countries), being ahead of South Africa (57), Brazil (61) and India (76). Among ex-USSR countries, covered by the study, Russia ranks fifth after Estonia (position 24), Latvia (34) Lithuania (39) and Moldova (43) [5].

The World Economic Forum ranked it the 45th in the Global Competitiveness Index by the innovation development factors in 2015 (score 4.44 on the scale of 7). At the same time, the prospect of Russia's innovative breakthrough in the next 5 years, according to an authoritative European organization is not obvious if the existing organizational and economic approaches and the pace of innovation sphere development persist. The diagnosed problem of Russia's innovative development is defined as a low level of technological innovation of the industrial sector. The share of industrial enterprises engaged in the development and introduction of technological innovations does not exceed $10 \%$ in this country, and the share of innovative products in the total volume of industrial production was only $7.8 \%$ in 2014 . For comparison, according to the same organization, the level of innovativeness in European countries is 30 to $70 \%$. That is what determines the low competitiveness of the products of the national industry in the domestic and foreign markets.

Innovations are the relevant, deeply and comprehensively studied both with hindsight and at present scientific issue. Over the last 25 years of scientific and theoretical research, stages and evolutionary models of the innovation process (linear, marketing, interactive, integrated, network) have been formalized.

At the same time, structural changes in the world economy, the new socio-economic and technological challenges, a continuous evolution of forms and methods in organization of the innovation process in the industry

\footnotetext{
a Corresponding author: gerash-tatyana@yandex.ru
} 
force to constant revise the existing set of knowledge [4]. That is why the existing methods of the innovation process management at an industrial enterprise can be studied and developed in the following scientific and theoretical directions:

- composition of functions of the innovation process in the industrial sector;

- institutional structure of the innovation participants in industry;

- organizational and economic interaction between the participants of the innovation process in the industrial complex based on the network paradigm.

In the given context, the object of this article is development of theoretical principles and methods to manage the innovation process at industrial enterprises on the basis of the network model.

The following tasks are set within the study objective:

1. Formalize the theoretical approaches to the study of innovation activity, to determine the specificity of innovation at industrial enterprises;

2. Improve the innovation processes management methods at industrial enterprises on the basis of the network model of interaction of economic entities;

3. Define the organizational and economic principles, approaches and mechanisms for managing the network innovative process of technological innovation.

The object of the study is the innovation process at the industrial enterprises of Russia.

The subject of the study is innovation process management methods aimed at increasing the level of innovation of industrial enterprises.

The scientific novelty of the research is to develop the innovation process management methods for industrial enterprises on the basis of a network approach.

\section{Materials and methods}

The methodological basis of the study is the principles of dialectical relationship between the subject and the object, the process and the result, single, special and general, the unity of traditions and approaches.

For this purpose, the general theoretical learning methods (analysis, synthesis, analogy, comparison, correlation, generalization, classification, systematization, abstraction, interpretation, analysis and synthesis of scientific literature and practical experience, etc.) were used in this research.

\section{Results and discussion}

The Russian industry transition to an innovative path of development, its focusing on the marketing paradigm, business practices in economic activity is a process that can be objectively assessed. The criterion of objectivity is the "innovation" variable that is the share of morally new (advanced by technical and economic performance and consumer demand) products in the revenue structure of enterprises, industry, and national turnover. The innovativeness level of the national industry was only
$4.6 \%$ in 2012 and this trend (in 4-year retrospective) is rather stable - the average deviation does not exceed $0.27 \%$. This value is critically low - as a comparison, the level of innovativeness in European countries is $30-70 \%$. The level of innovativeness in the mining sector of Russia looks alike $-2.7 \%$, in manufacturing $-2.2 \%$, with drastically low value even for high-tech industries $8.3 \%$. The value of these indicators is the reference point of the issue discussed in the study - the level of competitiveness and innovation of the national industry. And it looks like the problem is not so much in the low level of the index itself, as in the absence of its development trend and obvious prerequisites for extensive and intensive growth. The general analytical conclusion can be formulated as the stagnation of innovative development of the national industry.

The investigated innovative features of the industry (innovation and the cost of technological innovation), classified according to the predictability level (Table 1), allowed developing scientific understanding of the innovation activity in industry and concluding about the relationship between innovativeness and costs of the product and the process technological innovation.

Table 1. Innovative features of the sectors of industry of the Russian Federation, 2014

\begin{tabular}{|c|c|c|c|c|}
\hline \multirow{3}{*}{$\begin{array}{l}\text { Designa } \\
\text { tion }\end{array}$} & \multirow{3}{*}{$\begin{array}{l}\text { Classification of } \\
\text { industries by the } \\
\text { productivity level }\end{array}$} & \multicolumn{3}{|c|}{ Innovative features } \\
\hline & & \multirow{2}{*}{$\begin{array}{c}\text { Level of } \\
\text { innovati } \\
\text { veness, } \\
\%\end{array}$} & \multicolumn{2}{|c|}{$\begin{array}{c}\text { Cost distribution } \\
\text { on technological } \\
\text { innovation, } \%\end{array}$} \\
\hline & & & product & process \\
\hline A & Manufacturing & 2.2 & 60 & 40 \\
\hline A1 & High-tech industries & 8.3 & 75 & 25 \\
\hline $\mathrm{A} 2$ & $\begin{array}{l}\text { Medium technology } \\
\text { industries of a high level }\end{array}$ & 7.1 & 70 & 30 \\
\hline $\mathrm{A} 3$ & $\begin{array}{l}\text { Medium technology } \\
\text { industries of a low level }\end{array}$ & 4.2 & 40 & 60 \\
\hline A4 & Low-tech industries & 4.8 & 50 & 50 \\
\hline $\mathrm{B}$ & Mining & 2.7 & 10 & 90 \\
\hline
\end{tabular}

Innovation in the subsequent technology level in the industrial logistic chain is determined by implementation of the innovative potential of the preceding branches, (fig. 1).

We need a strategy and appropriate theoretical solutions for the associated and integrative development of the innovative potential, gaining innovation at all the technological levels of the industry. In sight of the industrial sector development, we can highlight the basic trend VI of technological mode - product innovations in the high-tech field, provided by the process innovations in the medium- and low-tech sectors.

The object of the study defines the innovation processes of industrial areas: we need to look for the new forms of organizational and economic interaction between the participants of innovation and management mechanisms for this interaction.

Formalization of the innovative characteristics of industries allowed formulating the principles of scientific research of innovation processes in the industry: the inclusion of suppliers, consumers and industrial infrastructure as the participants in the process; flexible, 
network, non-linear approaches to the organization of interaction of participants.

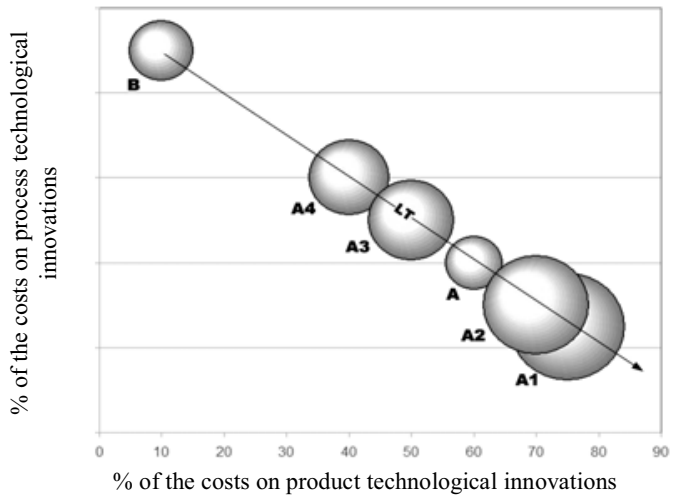

Fig. 1. Relationship (LT) between innovativeness (diameter) and a balance of expenditure for product and process technological innovation in the vertical logistic chain of the industry. Designations A, B, A1-A4 are the designations of the selected industries by the productivity level (Table 1).

In addition, a logical link in the chain of concepts is determined: technological mode - innovation cycle innovation process. The wave nature is defined by the general principle of the study of innovation modes, cycles, and processes. A technological mode is a set of technologies, specific to a certain production development level [1]. And an innovation cycle is a set of innovations (products and technologies), united by a single scientific, technological wave of development of innovations and modifications. The specific innovation process to introduce new technology or turn out of a morally new product (organizational and marketing innovations for the second time) is a part of the global innovation cycle, which is in turn conditioned by the actual scientific and technical areas within the technological mode.

It is necessary to highlight the functional components of the innovation process, which today are defined in science as its stages, phases.

The objective component of the innovation process determines the "interaction", expressed as the economics and management system. The proposed structure meets the theoretical principles of the system approach: the subject and their functions - system components; economics and management in the framework of operational processes - interaction of the system components. The essence of the definition of the innovation process determines the structure and its components as an object of research (process stages, functions, economics and management system; subjects, participants of the process).

Regardless of the sequence of operations in the innovation process, its informative nature is highlighted, which let us refer it to the traditional areas of professional activity.

This laid down definition allows formalizing the principles of selection the strategic functions of the innovation process of an industrial enterprise:
- permanence by the implementation, stable manifestation in the innovation process of professional competences;

- intensity by the interim result, which implies existence of the "objective product" of the operating activity;

- homogeneity by the content of professional competencies, which implies the interconnectedness of operations to specialize the performers, commonality of the used resources, fixed assets and funds of the technological process. In accordance with the principles, 11 strategic functions of the innovation process at the industrial enterprise were determined and formalized by their contents, and their meaning was disclosed, Table. 2.

Table 2. Strategic functions of the innovation process at the industrial enterprise

\begin{tabular}{|c|c|}
\hline $\begin{array}{l}\text { Strategic } \\
\text { functions }\end{array}$ & Content \\
\hline $\begin{array}{l}\text { Consumpti } \\
\text { on }\end{array}$ & $\begin{array}{l}\text { The process of acquisition and a subsequent } \\
\text { operation of innovative products. }\end{array}$ \\
\hline Marketing & $\begin{array}{l}\text { Evaluation of the market potential, competitiveness } \\
\text { of the innovation idea and subsequent } \\
\text { implementation of "marketing mix" complex } \\
\text { (promotion, pricing, positioning, commodity } \\
\text { clearance) to provide sales of the innovative } \\
\text { products. }\end{array}$ \\
\hline Investing & $\begin{array}{l}\text { Financing of the subjects, participants of the } \\
\text { innovation process }\end{array}$ \\
\hline $\begin{array}{l}\text { Applied } \\
\text { research } \\
\text { efforts }\end{array}$ & $\begin{array}{l}\text { Converting the results of basic research, } \\
\text { innovators' ideas and formalized requirements into } \\
\text { a new scientific and technical, technological, } \\
\text { organizational or marketing solution. }\end{array}$ \\
\hline $\begin{array}{l}\text { Design and } \\
\text { developme } \\
\text { nt work } \\
\text { (process } \\
\text { developme } \\
\text { nt work) }\end{array}$ & $\begin{array}{l}\text { Adaptation of the results of applied research to the } \\
\text { conditions and possibilities of production (or } \\
\text { organization of the technological process) of a } \\
\text { specific industrial enterprise, realized in the } \\
\text { prototype format and set of the design } \\
\text { (technological - in the case of the process } \\
\text { development work) documentation. }\end{array}$ \\
\hline $\begin{array}{l}\text { Technology } \\
\text { infusion }\end{array}$ & $\begin{array}{l}\text { Formation of a new technological process (as a self- } \\
\text { innovation), or implementation of a new production, } \\
\text { including development of the technological cycle } \\
\text { and acquisition of equipment and tooling. }\end{array}$ \\
\hline Production & $\begin{array}{l}\text { Duplication of innovative products based on the } \\
\text { launch of a series of new products or the } \\
\text { development of new technological principles of } \\
\text { production. }\end{array}$ \\
\hline $\begin{array}{l}\text { Supply and } \\
\text { logistics }\end{array}$ & $\begin{array}{l}\text { Provision of the process of duplication and } \\
\text { servicing in operation of innovative products with } \\
\text { raw materials, supplies and components. }\end{array}$ \\
\hline Trade & $\begin{array}{l}\text { Distribution of new products through the product } \\
\text { distribution channels to the consumer. }\end{array}$ \\
\hline Education & $\begin{array}{l}\text { Development of the consumers' skills of the } \\
\text { innovative products operation. }\end{array}$ \\
\hline Servicing & $\begin{array}{l}\text { The process of commissioning, maintenance and } \\
\text { subsequent decommissioning of innovative } \\
\text { industrial products, transferred for use to the } \\
\text { consumer. }\end{array}$ \\
\hline
\end{tabular}

The formulated essence of the subject of the innovation process is based on certain features of its economic behaviour. Isolation of innovative industrial business entities based on 3 stated signs [3]:

1. Display of specialization in activities, allocation of 
professional competence within the innovation process;

2. Development of institutions in the innovation sector to implement permanent strategic functions (Table 2);

3. The economic viability of specialization, functions of a member of the innovation process: the ability to identify and objectively assess the contribution (cost, value added cost, profit margin and other forms of economic objectification of the result) in the formation of an innovation.

The fundamental scientific and theoretical decision, first formalized by the author for the innovation network, is including the "consumer" in the subjects of the innovation process. The formulated solution is based on the analysis of the consumption function evolution in the industrial sector, the actual changes in its structural and content components. The basic organizational and economic mechanism of the industrial sector adaptation to the evolving structure is transition to the network models in the key - innovation - area of competitiveness formation.

The general model formation focus is the growth of innovative industry through introduction of the advanced - network - organization scheme for innovation process, corresponding to the industrial sector development tendencies. Four basic research theses, system prerequisites underlying the synthesis method of a standard innovative industrial enterprise network are as follows:

1. Network innovation process can be interpreted as a network, Innovation Network.

2. Innovation Network Nodes are the subjects, the participants of the innovation process;

3. Links between the nodes in the network are defined as implementation of strategic functions (Table 2) and addressing of the intermediate results of the innovation process phases;

4 Synthesis of innovation network shall be attributed to the criterion of its topology (inextricable links with the continuous developments, network evolution).

The method of allocating links in the innovation network that meets the 4 prerequisites, is based on determining critical, relevant and economically denominated bonds. These bonds let us form a matrix of total normalized estimates for significance of interactions in the network of the innovation process (Table 3 ).

Table 3. Matrix of total normalized estimates for significance of interactions in the network innovation process

\begin{tabular}{|l|c|c|c|c|c|c|c|c|c|}
\hline \multicolumn{1}{|c|}{ Subjects } & $\begin{array}{c}\text { Design } \\
\text { ation }\end{array}$ & C & T & I & N & O & P & L & E \\
\hline Consumer & C & & & & & & & & \\
\hline Trade & T & 0.64 & & & & & & & \\
\hline Investor & I & 0.55 & 0.31 & & & & & & \\
\hline $\begin{array}{l}\text { Design and } \\
\text { development } \\
\text { work }\end{array}$ & $\mathrm{N}$ & 0.17 & 0.34 & $\mathbf{0 . 5 5}$ & & & & & \\
\hline $\begin{array}{l}\text { Process } \\
\text { development } \\
\text { work }\end{array}$ & $\mathrm{O}$ & 0.09 & 0.018 & 0.02 & $\mathbf{0 . 5 2}$ & & & & \\
\hline Production & $\mathrm{P}$ & 0.48 & 0.87 & $\mathbf{0 . 8 8}$ & 0.49 & $\mathbf{0 . 9 7}$ & & & \\
\hline Logistics & $\mathrm{L}$ & 0.12 & 0.11 & 0.23 & 0.33 & 0.06 & $\mathbf{0 . 5 9}$ & & \\
\hline Education & $\mathrm{E}$ & 0.58 & 0.09 & 0.21 & 0.19 & 0.21 & 0.39 & 0.21 & \\
\hline Servicing & $\mathrm{S}$ & 0.67 & 0.18 & 0.09 & 0.18 & 0.31 & 0.49 & $\mathbf{0 . 6 1}$ & 0.09 \\
\hline
\end{tabular}

Implementation of the innovation network links determining method made it possible to identify and describe 11 significant interactions between subjects within the innovation process (Table 4).

A network graph makes it possible to assess the network topology, the availability of 'tails', to determine the 'shortest paths' of interaction between the nodes, and to complete other tasks aimed at construction of specific projections of innovative projects and functional expressions (economics, management, and others).

Table 4. Significant interactions in the network of the innovation process

\begin{tabular}{|l|l|}
\hline Code & \multicolumn{1}{|c|}{ Interactions } \\
\hline C01 & $\begin{array}{l}\text { The process of buying and consumption (operation) of } \\
\text { innovative products. }\end{array}$ \\
\hline C02 & $\begin{array}{l}\text { Lending, leasing and other forms of financial support } \\
\text { for the innovative products purchase and consumption } \\
\text { processes (servicing, education). }\end{array}$ \\
\hline C03 & $\begin{array}{l}\text { Consumer training in operation of the innovative } \\
\text { products. }\end{array}$ \\
\hline C04 & $\begin{array}{l}\text { Service support (technical and technological support, } \\
\text { repair, supply of engineering maintenance materials and } \\
\text { components) of the innovative products operation. }\end{array}$ \\
\hline T01 & $\begin{array}{l}\text { Transfer of innovative products for distribution in the } \\
\text { distribution networks. }\end{array}$ \\
\hline I01 & $\begin{array}{l}\text { Venture financing of the innovative product } \\
\text { development process or technological process. }\end{array}$ \\
\hline I02 & $\begin{array}{l}\text { Investing in the process technological innovations } \\
\text { (equipment, technology, engineering). }\end{array}$ \\
\hline N01 & $\begin{array}{l}\text { Development of the research prototypes and design } \\
\text { documentation basing on the results of the applied } \\
\text { process development work. }\end{array}$ \\
\hline O01 & $\begin{array}{l}\text { Technological introduction of the design documentation } \\
\text { (result of the design and development work) in } \\
\text { production. }\end{array}$ \\
\hline P01 & $\begin{array}{l}\text { Purchase of materials, components and raw materials for } \\
\text { production process. }\end{array}$ \\
\hline L01 & $\begin{array}{l}\text { Purchase of materials and components for servicing of } \\
\text { the innovation products in the course of their operation. }\end{array}$ \\
\hline
\end{tabular}

A network graph makes it possible to assess the network topology, the availability of 'tails', to determine the 'shortest paths' of interaction between the nodes, and to complete other tasks aimed at construction of specific projections of innovative projects and functional expressions (economics, management, and others).

The graph presented in fig. 2 is a standard, universal form of display of an innovation network - the result of scientific and theoretical research. Application of the graph to a specific innovative industrial cluster (projection) allows you to create organizational and economic mechanisms of interaction in the innovation cycle.

Analysis of the synthesized standard structure of the innovative industrial sector network (fig. 2) allows allocating two basic properties:

Ability to use as a model as an organizational and economic structure for the construction and development of regional industrial clusters and technological platforms of the national industry. 


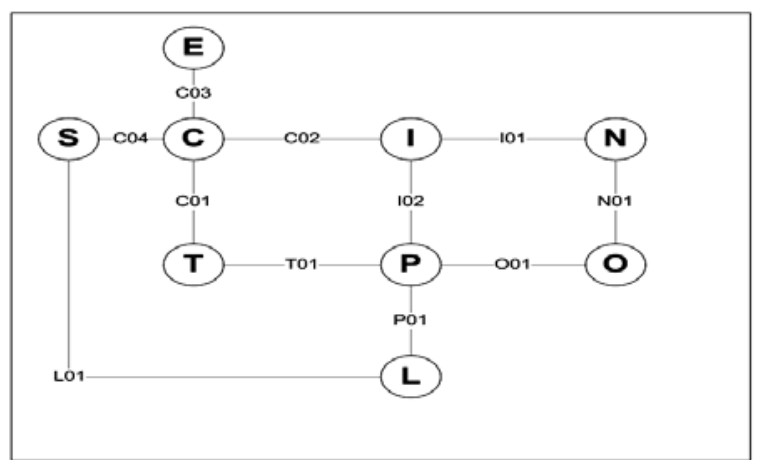

Fig. 2. The standard innovation network of an industrial enterprise. Symbols: Consumer $-\mathrm{C}$; Trade $-\mathrm{T}$; Investor - I; Design and development work - N; Process development work - O; Production - P; Logistics - L; Education - E; Servicing - S

Key subjects of the innovation network are the production and the consumer. They are aggregates of the chain of interactions in the innovation network (fig. 2), concentrate contractual relations and communication.

The end result of the innovative network introduction is reducing transaction costs of a cluster or a platform by increasing communication and contractual certainty of the content and direction of interactions (common property of the network models), as well as raising the level of competitiveness.

The economic and mathematical model to assess the prospect of forming an innovation network is expressed is terms of the gross margin:

$$
P B=Q-I-\sum_{i=1}^{9} C D_{i}-\sum_{i=1}^{9} C R_{i}
$$

Where: $\mathrm{PB}$ is the gross profit attributable to participants of industrial innovation network in the cycle;

$\mathrm{Q}$ is revenue, turnover from sales of innovative products to the consumer - the operating company;

$\mathrm{I}$ is investments attracted in the innovation process, including credit and leasing finance for buying an innovative product or a technology;

$$
\sum_{i=1}^{9} C D_{i}
$$
innovation network;

$$
\sum_{i=1}^{9} C R_{i}
$$
industrial innovation network.

Innovation network, as a solution to the problem of increasing innovativeness in the industrial sector, is also expressed in the appearance of the objective possibility of physical strategic planning - assessment of economic performance in the framework of the innovation cycle and mode.

The transition to the network organizational and economic platform, planning the multiplicity of process and product innovations, explaining the long-term economic benefits to the subjects, allowed framing a strategic innovative development plan.

Within its cycle and mode, the innovative network implemented many innovative solutions that significantly reduce the criticality level of the risks of individual innovations. The result is increased innovativeness of both separate network subjects, and economic productivity of the network union. Common understanding of the benefits of innovation networks is gaining competitiveness by both separate subjects and union in general. Competitiveness arises as a result of synergy of innovative potential of the subjects of innovative activity.

The proposed model can be used as a standard for organization of the innovation network, overlaid over actual organizational unions in the industrial sector, integrating the management mechanisms laid in them.

\section{Acknowledgment}

Thus, the definition of the essence and positioning of the innovative and investment strategy within the overall corporate strategy, formation and implementation of political decisions necessary for its implementation at all levels of the economy, can be the keystone to successful development of business entities in the long term.

\section{References}

1. Richard M. Walker, Jiyao Chen, Deepa Aravind European Management Journal, 33 (5), (2015)

2. Jarle Aarstad, Olav A. Kvitastein, Stig-Erik Jakobsen Research Policy, 45 (4), (2016)

3. Frank Ruff, Technological Forecasting and Social Change, 101, (2015)

4. N.V. Glushak, Yu.N. Katkow, O.V. Glushak, E.A. Katkowa, N.N. Kovalyova, Procedia - Social and Behavioral Sciences, 00, (2015)

5. https://www.globalinnovationindex.org/content/page/ GII-Home 